The Ranikot beds, long ago recognized as the basal division of the Eocene in Sind, have been shown to be of pre-Ypresian age. They are now known to be much more widely distributed than was formerly supposed, occurring also in the North-West Frontier Province, the Salt Range, Kashmir, Tibet, Burma, and western Iran. In the Samana Range (North-West Frontier Province) the Hangu Shale, with its rich fauna, seems to constitute the lowest fossiliferous horizon of this formation anywhere known; it is separated from Upper Cretaceous deposits by a conformable series of beds which, however, have yielded no fossils. A similar transition from the Cretaceous to the Eocene seems also to exist in Burma and possibly in Tibet.

In the Peninsular area interesting discoveries of fossils have recently been made in beds intercalated in and underlying the Deccan Trap; their study has led to the conclusion that the Trap belongs to the Lower Eocene rather than to the Cretaceous, as formerly supposed. The well-known Infra-Trappean bed of Rajahmundry would appear to lie almost upon the border-line between the Cretaceous and the Eocene. Prof. Rama Rao's own researches have led to the important new discovery of Lower Eocene beds overlying the Cretaceous in the Pondicherry district. Especial reference was mede to the study of the fossil algæe of many of the rocks under discussion, as this work is proving of great help in their correlation.

In discussing, next, the geography of early Eocene times, Prof. Rama Rao visualizes, in the west, an arm of the ancestral Indian Ocean stretching northward so as to cover Sind, Baluchistan, parts of the Punjab, the North-West Frontier Province, and Kashmir; and dividing, in the north, into two branches, which extended respectively to Iran and Tibet. A second arm of this sea, situated to the east of India, extended northward into parts of Assam and Burma. Reference was made to the divergent views of various authorities as to whether there was direct communication with the Mediterranean Sea of that period.

In his concluding remarks, Prof. Rama Rao pointed out that the great geographical changes which heralded the incoming of Tertiary times must everywhere have affected the balance of marine life ; hence a normally evolving succession of forms may not have persisted even in those parts of the sea where sedimentation was uninterrupted.

\section{Geography in National Planning}

The Section of Geography and Geodesy was formed on the occasion of the Jubilee meeting at Calcutta in January 1938, when its sessions were attended by a strong delegation from Britain. The president this year of the Section was Dr. S. P. Chatterjee, and in his presidential address he directed attention to the part which should be played by geographical studies in national planning.

A stock-taking of resources on a provincial basis is an essential pre-requisite of any work of national reconstruction, and that there is no country in the world where there is a greater need of a detailed land utilization survey than India. The assertions that in Bengal, which is selected for study as Dr. Chatterjee's native province, the land is deteriorating, soils losing fertility, marshes and lakes increasing in area at the cost of good arable lands, and riverborne sediment failing to build up the land, all require substantiation. The official statistics, skilfully shown in cartographic form, show that only one third of British India (contrasted with nearly half of 'Indian' India) is actually cropped. In Bengal, which in places supports a rural population, albeit in a condition very near the starvation level, of a thousand persons per square mile, no less than one quarter of the whole province is classed as fallow and cultivable waste, whilst less than half is actually cropped.

Dr. Chatterjee has clearly appreciated his training both in the French sehool and in Britain, and has attacked the problem on a regional basis. He gives the preliminary results of a survey carried out in the past two years and suggests a division of Bengal into ten regions. As frequently happens, the local cultivators know and appreciate small differences in soil and the local names (mainly based on texture) have been used to divide the new alluvium into ten types the distribution of which is shown on an instructive map.

As Chatterjee says, "since national planning means a conscious effort of man to change his environment in the best national interest, it is rational to be equipped with a thorough and accurate knowledge of the type, historic growth and present distribution of the various factors that go to form our cultural landscape, which is the subject matter of geography", and on this basis he appeals for an All-India organization for conducting a geographical survey.

( $T$ o be continued)

\title{
AIR CIRCULATION OVER INDIA
}

\begin{abstract}
A MEMOIR of the India Meteorological Eepartment (26, Part 10) by K. R. Ramanathan and K. P. Ramakrishnan, entitled "The General Circulation of the Atmosphere over India and its Neighbourhood", is probably the most complete account that has yet appeared of the average winds and temperatures in the upper atmosphere over India in each month of the year.

The observations of upper wind made with the aid of pilot balloons at observatories, and those of cloud movement, together with the measurements of temperature aloft by sounding balloon made at Agra, Poona and Hyderabad, form the basis of the
\end{abstract}

discussion. Mean isotherms for various levels up to $6 \mathrm{~km}$. were obtained partly from the changes of wind with height, from which the mean magnitudes and directions of the temperature gradients were calculated, and partly from the mean temperatures at the different heights for the three upper air observatories, supplemented in some cases by temperatures measured at Peshawur or Quetta. Although in theory it is sufficient, having obtained a chart of temperature gradient, to have the vertical distribution of temperature at only a single station in order to be able to draw the absolute values of the isotherms, in practice, the computations being only approximate 
at every stage, the accuracy of the final picture was increased by having means of temperature at several places.

The results are set out in 74 plates, the mean air movement being taken up to $8 \mathrm{~km}$. The main features of the upper wind and temperature distribution in the different months are discussed and then summarized (pp. 192-207). The most striking feature of the circulation is the regular seasonable movement of the upper wind system, which in the summer half of the year is from south-east to north-west and back, and in the remainder of the year is mainly from north to south and back. The smallness of the month to month movement from December to April or May is taken to signify that cooling and heating of the ground over India by radiation does not greatly modify the circulation, the big changes being caused by the northward penetration and the subsequent retreat of moist air from the southern hemisphere with its attendant rainfall.

Other striking features brought out by this study are the modifying influence of the Himalayas up to a height of $6 \mathrm{~km}$., and the fact that regions of heavy rainfall become regions of high temperature and divergence of air movement above $6 \mathrm{~km}$. The mean winds derived from cloud movement have a much larger northward component than those derived from pilot balloons, which last require absence of cloud so that the balloon can be followed. A true picture of average conditions cannot therefore be obtained from either method alone.

\section{ECONOMICS OF WAR-TIME EXPORT TRADE}

A VALUABLE broadshret "Exports in War" issued by Political and Economic Planning (P E P) reviews the question in relation to the economics of war and the principles upon which the export policy of Great Britain should be based. The object of exporting at all is to save man-hours, and in war-time to avoid mortgaging the future by the sale of overseas securities. Because of our limited ability to pay for imports in exports or foreign securities and our restricted capacity to ship them over, there must be discrimination between different types of demand for imports, giving priority to those which are most urgent from the point of view of winning the war.

The broadsheet stresses the basic importance of applied intelligence in exports; in war, it is particularly important to concentrate on those goods the selling price of which includes least matter and most mind, and the seller's market which is being created by the War should be utilized to grade up export industries instead of clinging to older and less profitable lines. Similarly, every opportunity missed. of improving productive efficiency is a drag on the national effort. If new layers of demand are continually tapped and labour and capital progressively transferred to more and more advanced processes or products, the shrinkage of formerly important export industries can be faced without dismay. Moreover, if we make the inter-allied economic arrangements between France and Great Britain work effectively, we shall not only have won the war but made also the greatest possible contribution towards winning the peace.

These agreements between France and Great Britain are outstanding among the actual War-time economic measures. With the joint committees on economic co-operation covering the supply and purchase of munitions, food and raw materials, shipping policy and economic warfare, they should lead to one economic policy for the two countries. This is specially true of exports. The three major elements in any export policy are the export potential, the available markets and the foreign trade policies. The nature of the export potential is the most important in a sellers' market, but exports cannot be left to take care of themselves after the needs of the armed forces and of the civilian population have been met, but must be recognized as a priority of the first importance. Among the opportunities for expansion of our exports at present, the broadsheet stresses those in machinery to complete unfinished German contracts, and those in cotton textiles, locomotives and coal.

The effect of the contraband control on export policy must next be recognized. The purpose of such control is to impede the supply of vital commodities to the enemy. This has now been extended to exports, so that Germany's direct overseas trade should soon be virtually destroyed. Particularly in Latin America, the control has created new markets for Great Britain, and for this our bargaining position is in general strong.

The second aspect of economic warfare consists in the extension of the effects of the blockade to the Continent, so as to cripple Germany's trade with those neutrals with whom contact can still be maintained. The object of promoting British exports to European countries is to turn the tide of trade heavily against Germany by raising the prices of neutral products. This involves a careful study of the strategy of economic warfare, if Germany is to be prevented from importing from neighbouring countries. Strategic purchases, for example, of Rumanian oil involve British exports to pay for them. Sound export policies, moreover, can only be framed after the fullest information about markets and resources has been obtained, and such policy covers every aspect of exporting from production to marketing, including the use of bilateral or multilateral methods of approach to markets, import or export subsidies.

A large-scale purchasing programme makes a survey of the export potential more urgent, and the existence of these Anglo-French programmes is an important factor for world producers. Overseas Governments will require to know that resources are available to supply the necessary goods if they are to continue to sell to Britain, and also that exports have priority over alternative demands. The importance of paying sufficient attention to the needs of the non-self-governing colonies is stressed in the broadsheet, which adds one further plea to the many already advanced for a co-ordinator of trade policy with sufficient political status, including access to the Cabinet, to secure the full and coherent use of Great Britain's immense resources for acting as a centre of world economic expansion. 